\title{
USE OF DIFFERENT INFILTROMETERS TO ASSESS ENVIRONMENTAL DAMAGE CAUSED BY DIFFERENT LAND USES
}

\author{
Igor Leonardo Nascimento Santos \\ Universidade Federal de Sergipe - UFS \\ Departamento de Engenharia Agrícola, São Cristovão, SE, Brasil \\ igorsantos1993@gmail.com \\ Raimundo Rodrigues Gomes Filho \\ Universidade Federal de Sergipe - UFS \\ Departamento de Engenharia Agrícola, São Cristovão, SE, Brasil \\ rrgomesfilho@hotmail.com \\ Alceu Pedrotti \\ Universidade Federal de Sergipe - UFS \\ Departamento de Engenharia Agronômica, São Cristovão, SE, Brasil \\ alceupedrotti@gmail.com \\ Gregorio Guirado Faccioli \\ Universidade Federal de Sergipe - UFS \\ Departamento de Engenharia Agrícola, São Cristovão, SE, Brasil \\ gregorioufs@gmail.com \\ Renisson Neponuceno de Araújo Filho \\ Universidade Federal de Tocantins - UFT \\ Departamento de Engenharia Florestal, Gurupi, TO, Brasil \\ renisson@uft.edu.br \\ Clayton Moura de Carvalho \\ Instituto Federal Baiano - IFBaiano \\ Campus Serrinha, Serrinha, BA, Brasil \\ cmcarvalho78@gmail.com \\ Sara Julliane Ribeiro Assunção \\ Universidade Federal de Sergipe - UFS \\ Departamento de Engenharia Agronômica, São Cristovão, SE, Brasil \\ sarassuncao6@hotmail.com
}

\begin{abstract}
The present work had an objective to compare the stable infiltration rate obtained by infiltrometers with reduced dimensions and varied forms in different land uses, in order to reduce the amount of water used and to facilitate the installation of infiltrometers. The infiltration tests were carried out in areas planted with cowpea, crotalaria, pigeon pea and millet, as crops previous to corn planting, and managed with no-tillage, minimum tillage and conventional tillage. The tests were also carried out in native forest area. Four infiltrometers set were used: double-ring infiltrometer (standard), double-ring reduced, single-ring and double square. In order to compare and analyze the results of the stable infiltration rates obtained between the alternative infiltrometers and the considered standard, the criteria involving the standard error of estimation (SEE), the standard error of estimation adjusted (SEEa), the standard error of estimation adjusted by origin (SEEao) and coefficients of adjustments of the linear equations with their respective determination coefficients $\left(R^{2}\right)$ were used. It was verified that the double-ring reduced, single-ring and double square infiltrometers provided water saving of $57.06 \%, 66.19 \%$ and $38.54 \%$ respectively, relative to the standard. The alternative infiltrometers overestimated the stable infiltration rate in relation to the standard. The single-ring infiltrometer obtained a stable infiltration rate correction equation that showed results very close to the standard and the best statistical indices of stable infiltration rate results were obtained by the reduced double-ring infiltrometer.
\end{abstract}

Keywords: Double-Ring infiltrometer. Single-Ring infiltrometer. Square infiltrometer. Impact soil. 


\title{
USO DE DIFERENTES INFILTRÔMETROS PARA AVALIAR DANOS AMBIENTAIS CAUSADOS POR DIFERENTES USOS DA TERRA
}

\begin{abstract}
RESUMO
O presente trabalho teve como objetivo comparar a taxa de infiltração estável obtida por infiltrômetros com dimensões reduzidas e formas variadas em diferentes usos do solo, a fim de reduzir a quantidade de água utilizada e facilitar a instalação de infiltrômetros. Os testes de infiltração foram realizados em áreas plantadas com feijão caupi, crotalária, feijão bóer e milho, como culturas anteriores ao plantio de milho, e manejadas com plantio direto, plantio mínimo e preparo convencional. Os testes também foram realizados em área de floresta nativa. Foram utilizados quatro infiltrômetros: infiltrômetro de anel duplo (padrão), anel duplo reduzido, anel simples e quadrado duplo. Para comparar e analisar os resultados das taxas de infiltração estáveis obtidas entre os infiltrômetros alternativos e o padrão considerado, os critérios que envolvem o erro padrão de estimativa (EPE), o erro padrão de estimativa ajustado (EPEa), o erro padrão de estimativa ajustados por origem (EPEao) e foram utilizados coeficientes de ajustes das equações lineares com seus respectivos coeficientes de determinação $\left(R^{2}\right)$. Verificou-se que os infiltrômetros com anel duplo reduzido, anel simples e quadrado duplo proporcionaram uma economia de água de $57,06 \%$, 66,19\% e 38,54\%, respectivamente, em relação ao padrão. Os infiltrômetros alternativos superestimaram a taxa de infiltração estável em relação ao padrão. 0 infiltrômetro de anel único obteve uma equação de correção da taxa de infiltração estável que apresentou resultados muito próximos do padrão e os melhores índices estatísticos de resultados da taxa de infiltração estável foram obtidos pelo infiltrômetro de anel duplo reduzido.
\end{abstract}

Palavras-chave: Infiltrômetro de anel duplo. Infiltrômetro de anel único. Infiltrômetro quadrado. Impacto do solo.

\section{INTRODUCTION}

The knowledge of soil water infiltration rate is of fundamental importance to define soil conservation techniques, to plan and delineate irrigation and drainage systems (GONDIM et al., 2010). Alves Sobrinho et al. (2003) said that at the beginning of the process, the soil water infiltration rate is high, decreasing with time until it becomes constant at the moment when the soil becomes saturated, being called the stable infiltration rate. The soil water infiltration rate is a variable that has been widely studied and should be measured by means of techniques capable to adequately represent the natural conditions in which the soil is found (CUNHA et al., 2009).

The determination of this soil water infiltration rate, according to Fagundes et al. (2012) can been determined by several methodologies, among them, it is possible to highlight the use of double-ring infiltrometers, being simple and easy to execute. On the other hand, Simões, Figuerêdo and Silva (2005) add that, the double-ring infiltrometers had the disadvantage of high water consumption during the tests, which may make it impossible to perform the test in areas with difficult access to water.

One of the main challenges for exhaustive land use is to try to curb the environmental impacts caused by the change in land use and occupation in rural areas. Such a change directly affects river basins, causing hydrological changes. One of the main changes is the increase in runoff, caused by soil compaction that overload drainage systems (KABIR et al., 2019)

In order to reduce the amount of water used and to facilitate the installation of the infiltrometers, this work was proposed, which aimed to estimate the soil water infiltration rate using infiltrometers with reduced size and varied forms in different uses of cultivated soil with cowpea antecedent to maize. 


\section{MATERIAL AND METHODS}

The experiment was carried out in an experimental area of the Experimental Station of the Federal University of Sergipe, located in the Poxim river basin (Figure 1), in the city of São Cristovão - SE, whose geographic coordinates of Greenwich are $10^{\circ}$ 9236'S for latitude and $37^{\circ} 1993^{\prime} \mathrm{W}$ for longitude (OLIVEIRA et al., 2017), the soil is classified as Ultisol (SANTOS et al., 2018). The region has a rainy climate with dry summer and an average rainfall of $1200 \mathrm{~mm}$ per year, with rainfall concentrated in the months of April to September.

Figure 1 - Map of land use and vegetation cover of the Poxim river basin.

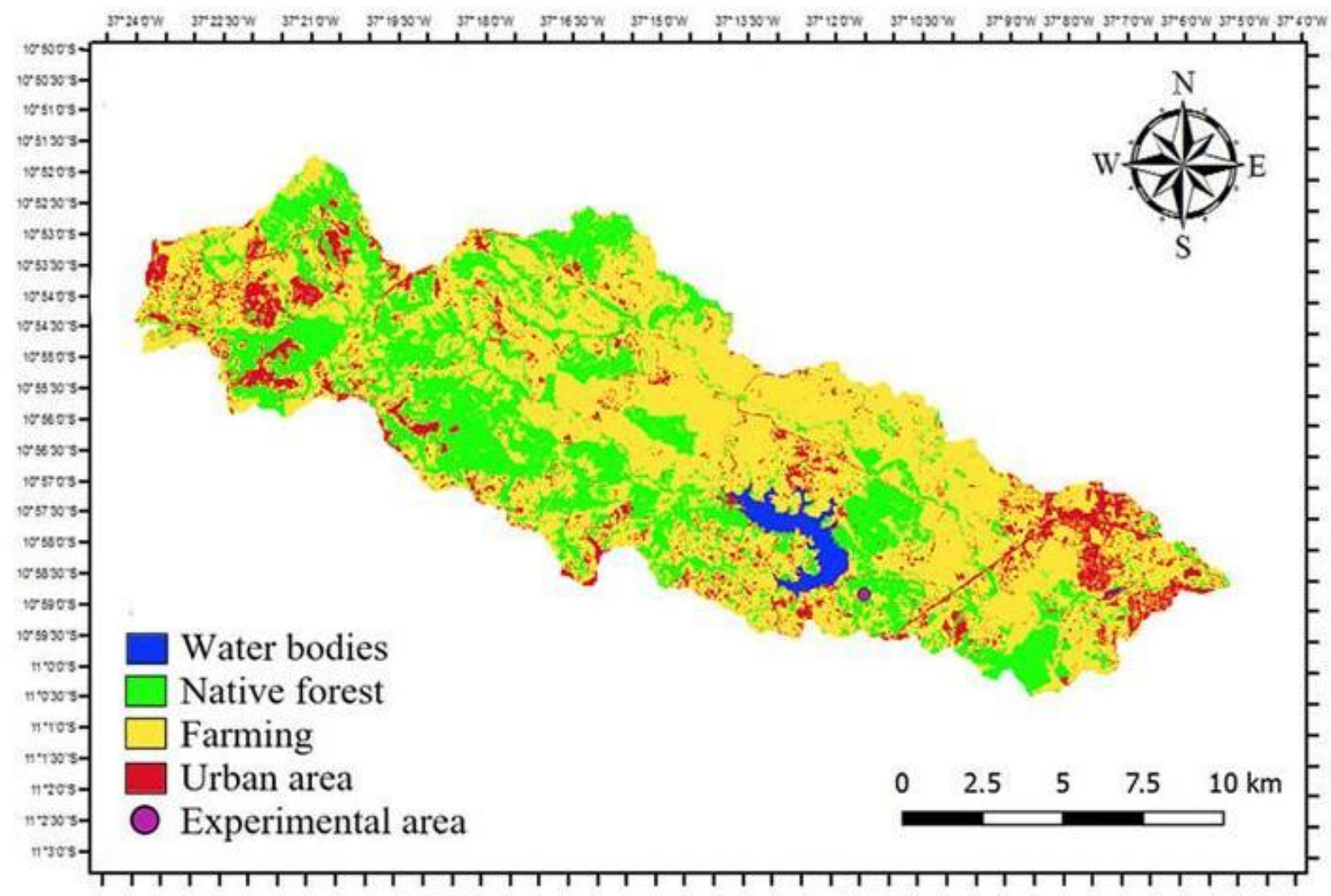

The experimental station area is surrounded by native forest and in the interior are conducted several experiments in several agricultural crops, among them, corn on several treatments, pasture and eucalyptus, characterizing well the uses of soil found in the basin.

The infiltration tests were carried out in an area of approximately $3000 \mathrm{~m}^{2}$, where Biomatrix corn variety BM 3061 has been planted since 2001, the variety has a dual purpose, ears of corn and green matter for fodder, on three types of management, conventional tillage, where the disc leveling grid and the disk plowing were used; minimum tillage, which used only the grading grid for soil revolution; and no-tillage, which does not use any agricultural machinery. These three managements represented three different parcels in the area, inside of each parcel there were twelve subparcels, where four antecedent crops were planted in three replicates, randomly distributed, used only for protection and improvement of the soil: cowpeas (Vigna unguiculata L. Walp.), crotalaria (Crotalaria juncea), pigeon pea (Cajanus cajan) and millet (Pennisetum glaucum (L.) R. Br.).

The size of the area and the position of the antecedent crops can be observed in Figure 2. In addition to the described agricultural area, tests were carried out in the native forest located nearby. 
Figure 2- Schematic of the area with the dimensions and arrangement of antecedent crops under different uses.

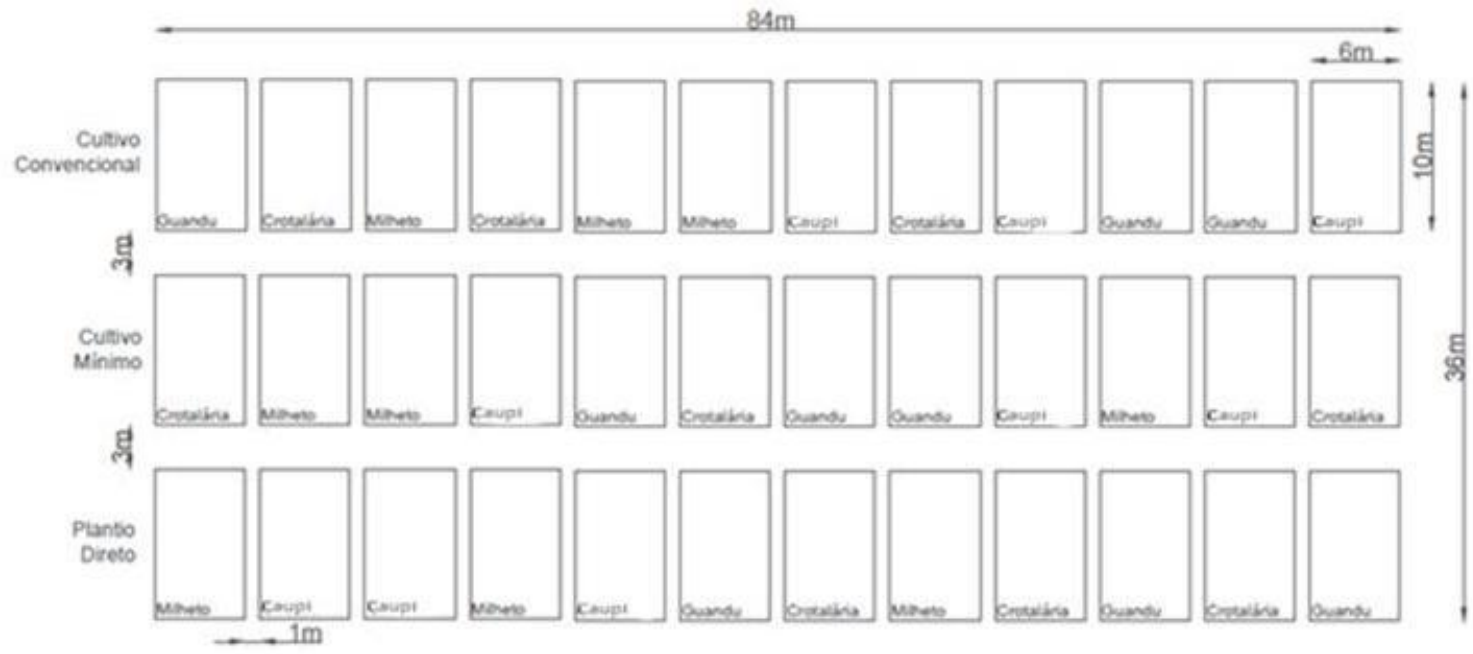

The soil water infiltration tests were carried out following the methodology of the double-ring infiltrometer and the single-ring infiltrometer, described by Brandão et al. (2006), using infiltrometer of different sizes and varied forms (Table 1).

Table 1 - Dimensions and shapes of infiltrometers.

\begin{tabular}{ccc}
\hline \multirow{2}{*}{ Infiltrometers } & \multicolumn{2}{c}{ Dimensions $(\mathrm{cm})$} \\
\cline { 2 - 3 } & Internal & External \\
\hline Double-ring & 25 & 50 \\
Reduced double-ring & 15 & 30 \\
Single-ring & 30 & - \\
Double Square & 15 & 30 \\
\hline
\end{tabular}

The double-ring infiltrometer with internal diameter of $25 \mathrm{~cm}$ and external of $50 \mathrm{~cm}$ was considered as standard and the others as alternative.

To improve standardization between tests, all infiltrometers were installed at a depth of $10 \mathrm{~cm}$ and the readings followed the time interval pattern of $0,2,5,5,10,10,15,15,20,20,20$ minutes, repeating 20 minutes' readings until the infiltration stabilized, at the beginning of the test and at the end of each reading the water slide was replenished to a height of $10 \mathrm{~cm}$. For statistical purposes, three replicates were performed for each infiltrometer in each type of soil use. Figure 3 shows the infiltrometers installed in the field.

Figure 3 - Double-ring infiltrometer $(A)$, reduced double-ring infiltrometer $(B)$ and double square infiltrometer $(C)$

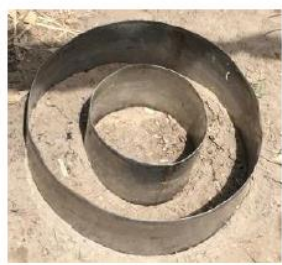
installed in field.

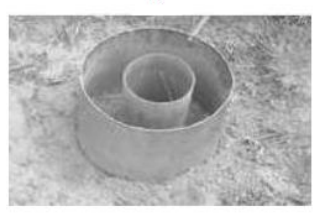

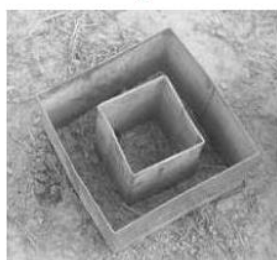


In order to compare and analyze the results of the stable infiltration rates obtained between the alternative infiltrometers and the considered standard, the criteria involving the standard error of estimation (SEE), the standard error of estimation adjusted (SEEa), the standard error of estimation adjusted by origin (SEEao) and coefficients of adjustments of the linear equations with their respective determination coefficients $\left(\mathrm{R}^{2}\right)$ were adopted (JENSEN, BURMAN, ALLAN,1990).

$$
\begin{aligned}
& \mathrm{SEE}=\left(\frac{\sum\left(\mathrm{Y}_{\mathrm{i}}-\mathrm{Y}_{\mathrm{m}}\right)^{2}}{\mathrm{n}-1}\right)^{0,5} \\
& \mathrm{SEE}_{\mathrm{a}}=\left(\frac{\sum\left(\mathrm{Y}_{\mathrm{i}}-\mathrm{Y}_{\mathrm{m}}\right)^{2}}{\mathrm{n}-1}\right)^{0,5}
\end{aligned}
$$

Where $\mathrm{Yi}$ is the infiltration rate obtained by the alternative infiltrometer set (mmh-1), $\mathrm{Ym}$ is the infiltration rate obtained by the standard infiltrometer $(\mathrm{mmh}-1), \mathrm{n}$ is the total number of observations and $Y$ ic is the infiltration rate obtained by the alternative infiltrometer set corrected by linear regression coefficients (mmh-1).Statistical Analysis

The soil water infiltration rates were also submitted to the Tukey test, with a $5 \%$ probability, using SISVAR 5.6 software from the Federal University of Lavras (FERREIRA, 2011).

\section{RESULTS AND DISCUSSION}

In order to observe the water saving, the average of the volume of water used in all of the infiltration tests was calculated. The standard infiltrometer used an average of 42.13 liters of water per test, while the reduced double-ring, single-ring and double square infiltrometers used an average of $18.09,14.24$ and 25.89 liters of water, which represented a reduction consumption of $57.06 \%, 66.19 \%$ and $38.54 \%$ respectively, showing a satisfactory result.

Gomes Filho et al. (2014) using reduced double-ring infiltrometers with 10 and $20 \mathrm{~cm}$ of internal and external diameter, respectively, to determine the water infiltration rate in a dystroferric Red Latosol managed with conventional tillage, obtained a reduction in water consumption of $84.2 \%$, higher than that found in this work, but proportional.

With the objective of this study, the relationship of stable infiltration rate found by each infiltrometer, data were plotted from all points obtained in fields, where the coordinate was used as the data of the standard infiltrometer and in the abscissa the data of the alternative infiltrometer, the trend line was forced on the origin so that an equation of adjustment was generated correlating the alternative infiltrometer with the standard for the different uses of the soil. The result can be seen in Figures 4,5 and

Figure 4 - Relation of the stable soil water infiltration rate obtained by the double-ring and reduced double-ring infiltrometer.

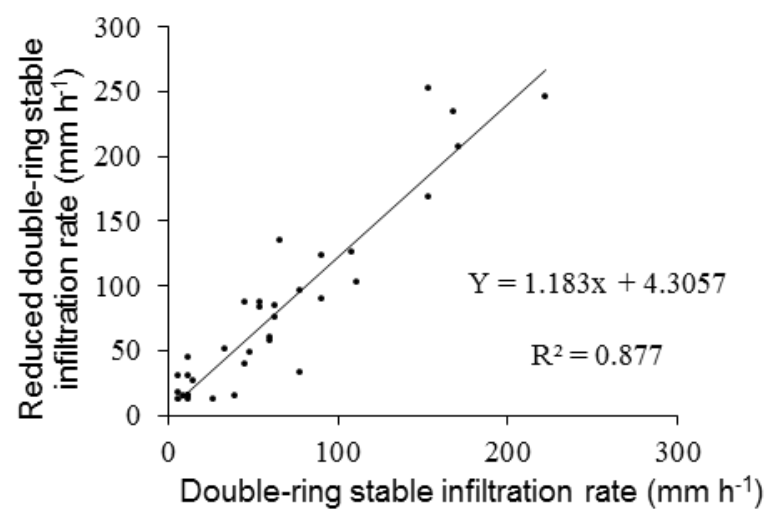


Figure 5 - Relation of the stable soil water infiltration rate obtained by the double-ring and single-ring infiltrometer.

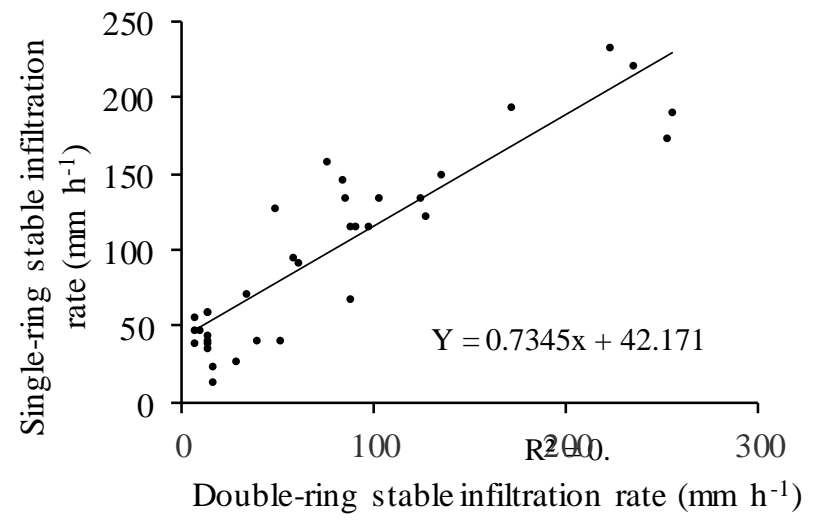

Figure 6 - Relation of the stable soil water infiltration rate obtained by the double-ring and square infiltrometer.

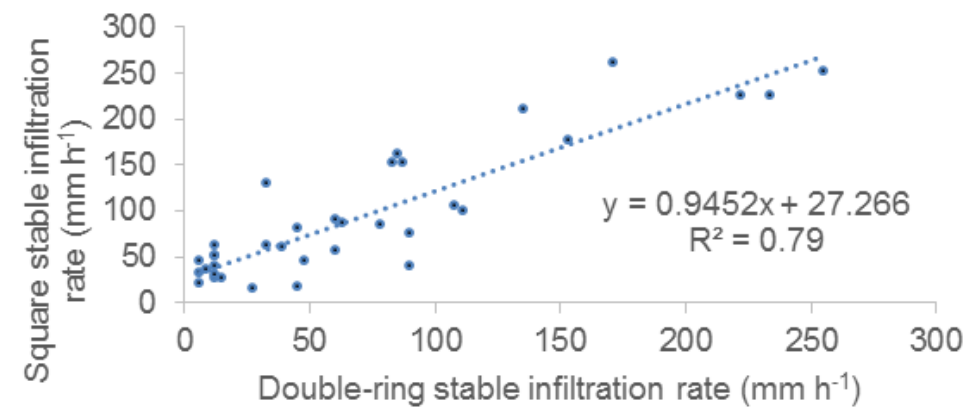

According to the results of Figures 4, 5 and 6, it was verified that the reduced double-ring provided a better correlation results than the other alternative infiltrometers.

The correlation between the stable infiltration rate values obtained by the reduced double-ring and the standard (88\%) was close to that obtained by Gomes Filho et al. (2014), who compared the stable infiltration rate obtained by a double-ring and a reduced double-ring, obtained a correlation of $91 \%$.

It was observed through the generated linear equations that all the alternative infiltrometers overestimated the stable infiltration rate in relation to the standard infiltrometer. In tests that related the dependence on the diameter of double-ring infiltrometer and the measured hydraulic conductivity, Lai and Ren (2007) observed that larger cylinders tended to obtain lower rates of stationary infiltration, a fact that can be explained by the increase of the edge that avoids the horizontal movement in the ground.

Burgy and Luthin (1956) comparing infiltrations obtained by the double-ring infiltrometer, single-ring infiltrometer and by the basin method, which was considered standard, observed that the single-ring infiltrometer overestimated the values found by the double-ring infiltrometer and complete saying that the sizes of the external rings should be large enough to mask the lateral flow contribution to total infiltration, particularly on the initial soil moisture.

Therefore, for the use of alternative infiltrometers, it is recommended to multiply the stable infiltration rate by a factor less than one to perform the correction, thus, was generated the equations 3,4 and 5 , which can be used to adjust the stable infiltration rate of the alternative infiltrometers to the standard. 


$$
\begin{aligned}
& V I B_{\text {standard }}=0.8183 \mathrm{VI} B_{\text {reduceddoble-ring }} \\
& V I B_{\text {standard }}=0.9785 \mathrm{VIB}_{\text {single-ring }} \\
& V I B_{\text {standard }}=0.8707 \mathrm{VIB} B_{\text {doublesquare }}
\end{aligned}
$$

In Table 2, the results of the standard error of estimation (SEE) and the standard error of the adjusted estimate (SEEa) coefficients were set for the comparison between the alternative and standard infiltrometer.

Table 2 - Standard error of estimation (SEE) and standard error of adjusted estimate (SEEa) in $\mathrm{mm} \mathrm{h}^{-1}$ with respect to the complete linear regression and forced by the origin, for comparison between the alternative infiltrometers and the standard.

\begin{tabular}{cccc}
\hline & $\begin{array}{c}\text { Reduced double-ring } \\
(\mathrm{o} 15 \times 30 \mathrm{~cm})\end{array}$ & $\begin{array}{c}\text { Single-ring } \\
(\mathrm{o} 30 \mathrm{~cm})\end{array}$ & $\begin{array}{c}\text { Double square } \\
(\square 15 \times 30 \mathrm{~cm})\end{array}$ \\
\hline SEE $\left(\mathrm{mm} \mathrm{h}^{-1}\right)$ & 29.35 & 37.76 & 38.76 \\
SEEa $\left(\mathrm{mm} \mathrm{h}^{-1}\right)$ & 23.27 & 25.20 & 31.39 \\
$\operatorname{SEEaO}\left(\mathrm{mm} \mathrm{h}^{-1}\right)$ & 23.39 & 35.68 & 36.20 \\
\hline
\end{tabular}

* SEEao $=$ standard error of the adjusted estimate in relation to the linear regression forced by the origin.

It was possible to notice that the SEE was larger than the SEEao, which was larger than the SEEa, which indicates that the linear regression improved the fit. It was also possible to observe that the reduced double-ring infiltrometer provided smaller errors. This result corroborates with those obtained by Gomes Filho et al. (2014) who also showed an improvement of the linear regression adjustment when comparing a reduced double-ring infiltrometer with the double-ring infiltrometer in determining the stable soil water infiltration rate.

On the other hand, assuming that the average of the stable infiltration rate found by the reduced double-ring was $92.77 \mathrm{~mm} \mathrm{~h}^{-1}$, the SEEao could represent approximately $25.2 \%$ of this value, in the case of the single-ring, which obtained $108.61 \mathrm{~mm} \mathrm{~h}^{-1}$, the SEEao could represent approximately $32.8 \%$ and the double square represented $33.5 \%$, since its average was $108 \mathrm{~mm} \mathrm{~h}^{-1}$.

According to the results of Tukey's test observed in Table 3 , the best results were found by the reduced double-ring infiltrometer, where the stable infiltration rate deferred only in the conventional tillage area with the use of cowpea as antecedent and in the no-tillage area with pigeon pea as antecedent. The single-ring infiltrometer deferred in five different areas and the double square in four different areas. However, in most areas, all alternative infiltrometers did not defer from the standard infiltrometer. 
Use of different infiltrometers to assess environmental damage caused by different land uses

Igor Leonardo Nascimento Santos

Raimundo Rodrigues Gomes Filho

Alceu Pedrotti

Gregorio Guirado Faccioli

Renisson Neponuceno de Araújo Filho

Clayton Moura de Carvalho

Sara Julliane Ribeiro Assunção

Table 3 - Stable infiltration rate values obtained by the alternative and standard infiltrometers for all treatments.

\begin{tabular}{|c|c|c|c|c|c|c|}
\hline & Double-ring & $\begin{array}{c}\text { Reduced } \\
\text { double-ring }\end{array}$ & $\begin{array}{l}\text { Single- } \\
\text { ring }\end{array}$ & $\begin{array}{l}\text { Double } \\
\text { square }\end{array}$ & & \\
\hline \multicolumn{5}{|c|}{ Stable rate $\left(\mathrm{mm} \mathrm{h}^{-1}\right)$} & $\mathrm{EP}\left(\mathrm{mm} \mathrm{h}^{-1}\right)$ & CV (\%) \\
\hline \multicolumn{7}{|c|}{ Conventional tillage } \\
\hline Cowpea & $10 \mathrm{a}$ & $35 \mathrm{~b}$ & $51 \mathrm{~b}$ & $37 \mathrm{~b}$ & 5.05 & 26.31 \\
\hline Crotalaria & $18 \mathrm{a}$ & $18 \mathrm{a}$ & $29 a$ & $24 \mathrm{a}$ & 3.94 & 29.97 \\
\hline Pigeon pea & $11 \mathrm{a}$ & $15 \mathrm{a}$ & $49 \mathrm{~b}$ & $50 \mathrm{~b}$ & 4.97 & 27.57 \\
\hline Millet & $8 \mathrm{a}$ & $14 a b$ & $46 c$ & $35 \mathrm{bc}$ & 4.77 & 32.08 \\
\hline \multicolumn{7}{|c|}{ Minimum tillage } \\
\hline Cowpea & $55 \mathrm{a}$ & $52 \mathrm{a}$ & $77 \mathrm{a}$ & $55 a$ & 14.21 & 41.20 \\
\hline Crotalaria & $60 \mathrm{a}$ & $64 \mathrm{a}$ & $60 \mathrm{a}$ & $76 \mathrm{a}$ & 26.98 & 71.90 \\
\hline Pigeon pea & $93 \mathrm{a}$ & $107 \mathrm{ab}$ & $129 \mathrm{~b}$ & $86 a$ & 7.82 & 13.07 \\
\hline Millet & 66 a & $84 \mathrm{a}$ & $115 \mathrm{a}$ & $69 \mathrm{a}$ & 16.55 & 34.34 \\
\hline \multicolumn{7}{|c|}{ No-tillage } \\
\hline Cowpea & $287 \mathrm{a}$ & $214 a$ & $210 a$ & $279 a$ & 59.25 & 41.47 \\
\hline Crotalaria & $64 \mathrm{a}$ & $72 \mathrm{a}$ & $117 \mathrm{a}$ & $128 \mathrm{a}$ & 31.22 & 56.77 \\
\hline Pigeon pea & $57 \mathrm{a}$ & $85 b$ & $133 c$ & $156 d$ & 4.88 & 7.87 \\
\hline Millet & $122 \mathrm{a}$ & $264 \mathrm{a}$ & $166 \mathrm{a}$ & $188 \mathrm{a}$ & 31.83 & 29.80 \\
\hline \multicolumn{7}{|c|}{ Native forest } \\
\hline & $207 \mathrm{a}$ & $182 \mathrm{a}$ & $230 \mathrm{a}$ & $221 \mathrm{a}$ & & \\
\hline
\end{tabular}

* Means followed by the same letter in the row, did not differ statistically significantly by the Tukey Test $(p=0.05)$.

It was also possible to see that in only one area (no-tillage with pigeon pea cultivation as antecedent to maize), the infiltrometers completely differed among themselves, this phenomenon happened due to the proximity between the infiltration rate results found in the replicates, resulting in a coefficient of variation of $7.85 \%$, the lowest among all treatments and standard error of 4.882 , very low for means within the treatment.

The best results of soil water infiltration rate were obtained for the no-tillage system when compared to conventional and minimal planting systems. This fact can be explained because soils in no-tillage systems present a predominance of cavities and biological channels, due to the preservation of the biological activity and a reduction in soil compaction.

Similarly, Santos et al. (2016) observed that a soil managed under no-tillage, in relation to the other managements, proved to be more favourable as regards soil water infiltration, when they compared the infiltration speed of an Ultisol in different soil use managements and with the crotalaria (Crotalaria juncea) crop as cover in succession to the sweet corn crop (Zea mays L.).

Millet and cowpea crops used as cover prior to the planting of corn provided better results of soil water infiltration rate for the no-tillage system, indicating the influence of the type of soil cover (Table 3).

Vilarinho et al. (2019), evaluating the velocity of water infiltration into the soil by the ring infiltration method, in a Plintosolo Pétrico in two soil covers, Cerrado and pasture, concluded that the soil water infiltration was influenced by the covers and land use, corroborating with the results found in this study. 
Sales and Targa (2017), analyzing the basic infiltration rate in soils with different uses and coverings in the Itaim River basin in the municipality of Taubaté in São Paulo, using double infiltrating cylinders, observed that the different uses and occupations of the soils in the Itaim River basin presented different characteristics of soil water infiltration.

\section{CONCLUSIONS}

The single-ring infiltrometer used less water in the tests to determine the stable soil water infiltration rate and obtained a correction equation of the stable infiltration rate with results very close to the standard.

Among the alternative infiltrometers, the reduced double-ring infiltrometer obtained the best statistical results in obtaining infiltration rate in comparison to the infiltrometer of standard size and shape.

Os diferentes usos e coberturas do solo influenciaram na velocidade de infiltração da água no solo obtida por diferentes infiltrômetros.

\section{ACKNOWLEDGEMENT}

The authors thank FAPITEC / SE and CAPES for financial support and UFS for the provision of equipment and experimental area.

\section{REFERENCES}

ALVES SOBRINHO, T.; VITORINO, A.C.; SOUZA, L.C.D.; GONÇALVES, M.C.; CARVALHO, D. Infiltração de água no solo em sistemas de plantio direto e convencional. Revista Brasileira de Engenharia Agrícola e Ambiental, v.7, n.2, p.191-196. 2003. https://doi.org/10.1590/S1415$\underline{4662003000200001}$

BRANDÃO, V.S.; CECÍLIO, R.A.; PRUSKI, F.F.; SILVA, D.D. da. Infiltração da água no solo. 3a . Edição, Viçosa, UFV, 120p. 2006.

BURGY, R.H.; LUTHIN, J.N. A test of the single-and double-ring types of infiltrometers. Eos, Transactions American Geophysical Union, v.37, n.2, p.189-192. 1956. https://doi.org/10.1029/TR037i002p00189

CUNHA, J. L.X.L.; ALBUQUERQUE, A.W.; SILVA, C.A.; DE ARAÚJO, E.; DOS SANTOS JUNIOR, R.B. Velocidade de infiltração da água em um latossolo amarelo submetido ao sistema de manejo plantio direto. Revista Caatinga, v.22, n.1, p. 199-205. 2009.

FAGUNDES, E.A.A.; KOETZ, M.; RUDEL, N.; SANTOS, T.D.; PORTO, R. Determinação da infiltração e velocidade de infiltração de água pelo método de infiltrômetro de anel em solo de cerrado no município de Rondonópolis-M T. Enciclopédia Biosfera, Centro Científico ConhecerGoiânia, v.8, n.14, p. 369. 2012.

FERREIRA, D.F. Sisvar: a computer statistical analysis system. Ciência e Agrotecnologia, v.35, n.6, p. 1039-1042. 2011. https://doi.org/10.1590/S1413-70542011000600001

GOMES FILHO, R.R.; RODRIGUES, M.H.; LEITE JUNIOR, J.B.; COSTA, C.A.G.; FREITAS, D.S.; LIMA, T.P. Water infiltration soil using cylinders infiltrometers of reduced dimensions, Anais... Inovagri International Meeting. 2014. Fortaleza. Inovagri Meeting, p. 75-81. 2014. https://doi.org/10.12702/ii.inovagri.2014-a107

GONDIM, T.M.S.; WANDERLEY, J.A.C.; DE SOUZA, J.M.; FEITOSA FILHO, J.C.; DA SILVA

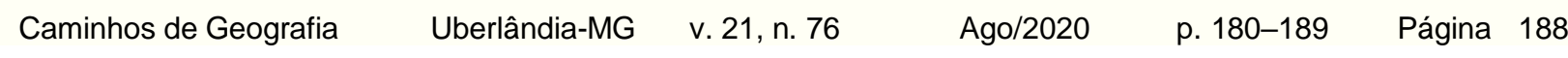


SOUSA, J. Infiltração e velocidade de infiltração de água pelo método do infiltrômetro de anel em solo areno-argiloso. Revista Brasileira de Gestão Ambiental, v.4, n.1, p. 64-73. 2010.

JENSEN, M.E.; BURMAN, R.D.; ALLEN, R.G. Evapotranspiration and irrigation water requirements. ASCE Manuals and Reports on Engineering Practice no. 70. Am. Soc. Civil Eng. New York, 1990.

LAI, J.; REN, L. Assessing the size dependency of measured hydraulic conductivity using double-ring infiltrometers and numerical simulation. Soil Science Society of American Journal, v.71, n.6, p. 1667-1675. 2007. https://doi.org/10.2136/sssaj2006.0227

KABIR, E.B.; BASHARI, H.; BASSIRI, M.; MOSADDEGHI, M.R. Effects of land-use/cover change on soil hydraulic properties and pore characteristics in a semi-arid region of central Iran. Soil and Tillage Research, v.197, p. 104478. 2020. https://doi.org/10.1016/j.still.2019.104478 https://doi.org/10.1016/..still.2019.104478

OLIVEIRA, F.C.C.; PEDROTTI, A.; FELIX, A.G.S.; SOUZA, J.L.S.; HOLANDA, F.S.R.; JUNIO, A.V.M. Características químicas de um Argissolo e a produção de milho verde nos Tabuleiros Costeiros sergipanos. Revista Brasileira de Ciências Agrárias, v.12, n.3, p. 354-360. 2017. https://doi.org/10.5039/agraria.v12i3a5464

SALES, P. A.; TARGA, M. S. Infiltração de água em diferentes usos e ocupação dos solos na bacia do rio Una em Taubaté, SP. Repositório de Ciências Ambientais, v.1, n.1, p. 1-13. 2017.

SANTOS, I.L.N.; GOMES FILHO, R.R.; CARVALHO, C.M. de; SANTOS, K.V.; OLIVEIRA, D.T.B.; SOUZA, L.G. Velocidade de infiltração da água no solo cultivado por milho doce com cobertura de crotalária. Revista Brasileira de Agricultura Irrigada, v.10, n.5, p. 925-934. 2016. https://doi.org/10.7127/rbai.v10n500469

SANTOS, H.G.; JACOMINE, P.K.T.; DOS ANJOS, L.H.C.; OLIVEIRA, V.A.; LUMBRERAS, J.F.; COELHO, M.R.; ALMEIDA, J.A.; ARAÚJO FILHO, J.C.; OLIVEIRA, J.B.; CUNHA, T.J.F. Sistema Brasileiro de Classificação de Solos. 5. ed. Brasília: Embrapa Solos, 2018. 355p.

SIMÕES, W.L.; FIGUEIRÊDO, V.B.; SILVA, E.L. da. Uso do cilindro infiltrômetro único em diferentes solos. Engenharia Agrícola, v.25, n.2, p. 359-366. 2005. https://doi.org/10.1590/S0100-69162005000200009

VILARINHO, M.K.C.; NASCIMENTO, J.C.; SILVA, T.J.A. da; ISQUIERDO, E.P.; CALDEIRA, D.S.A.; OLIVEIRA, C.P. Velocidade de infiltração básica de um plintossolo pétrico situado em áreas de pastagem e cerrado. Revista Brasileira de Agricultura Irrigada, v.13, n.2, p. 3336-3345. 2019. https://doi.org/10.7127/RBAI.V13N2001042

Recebido em: 24/01/2020

Aceito para publicação em: 30/06/2020 